\title{
The Origin of Hypertriglyceridemia in Streptozotocin Diabetic Rats*
}

\author{
J.D. Schnatz, J.M. Formaniak, and C. Chlouverakis \\ Department of Medicine, State University of New York at Buffalo, and the E.J. Meyer Memorial Hospital, Buffalo, \\ New York \\ Received: September 30, 1971, accepted: December 18, 1971
}

Summary. The effect of diet on the origin of hypertriglyceridemia seen in experimental diabetes was studied in streptozotocin diabetic rats after insulin treatment for one month and two days after insulin withdrawal. The data indicate that both exogenous and endogenous types of hypertriglyceridemia were present in insulin treated streptozotocin diabetes but that the exogenous component predominated during the period of insulin treatment and was independent of the amount of dietary fat. After insulin withdrawal there was a rise in serum triglyceride which was mainly reflected in the endogenous component. The data imply that dietary sucrose or protein might have contributed to this endogenous hypertriglyceridemia.

L'origine de l'hypertriglycéridémie chez les rats rendus diabétiques par la streptozotocine

Résumé. L'influence du régime alimentaire sur l'origine de l'hypertriglycéridémie observée dans le diabète expérimental a été étudiée après un mois de traitement à l'insuline et deux jours après arrêt du traitement chez un groupe de rats rendus diabétiques par administration de streptozotocine. Nos résultats indiquent la présence des deux types exogène et endogène d'hypertriglycéridémie dans le diabète dû̀ à la streptozotocine et traité à l'insuline, mais avec prédominance de l'apport exogène pendant la période de traitement à l'insuline, et ceci indépendamment de la quantité de graisse dans le régime. Après arrêt du

Hypertriglyceridemia frequently accompanies diabetes mellitus in various stages of control but its origin is still unsettled. Lipoprotein lipase which appears to be largely responsible for the removal of triglyceride from plasma was shown to be decreased during acute deprivation of insulin in alloxan diabetic rats [1]. Subsequently, in non-treated, chronically diabetic rats it was shown that hypertriglyceridemia developed on a high fat diet but was absent on a fat free diet [2]. Thus, the experimental hypertriglyceridemia of alloxanized rats was presumed to be of exogenous origin and a counterpart of the exogenous hypertriglyceridemia with decreased lipoprotein lipase activity seen clinically [3].

Yet, the concept that the hypertriglyceridemia of insulin deficient states is only exogenous in origin is in conflict with other studies showing elevated endogenous lipoprotein in plasma from patients with mild diabetes mellitus [4], ketoacidosis [5] or rabbits with uncontrolled alloxan diabetes [6].

* Presented in part at the Southern Section, American Federation for Clinical Research, New Orleans, Louisiana, January 1971. traitement à l'insuline nous avons observé une hausse de l'hypertriglycéridémie causée en grande partie par l'apport endogène. Nos résultats suggèrent que cette hypertriglycéridémie endogène peut dépendre de la contribution du saccharose ou de la fraction protéique du régime.

Die Ursache der Hypertriglyceridaemie bei streptozotocin. diabetischen Ratten.

Zusammenfassung. Der Effekt von Diät auf die Ursache der Hypertriglyceridaemie beim experimentellen Diabetes wurde bei Streptozotocin-diabetischen Ratten während einer einmonatigen Insulinbehandlung und auch zwei Tage nach Unterbrechung der Behandlung untersucht. Die Ergebnisse zeigen, daß exogene wie auch endogene Hypertriglyceridaemie-Komponenten bei mit Insulin behandelten Streptozotocin-diabetischen Ratten vorhanden sind, daß aber die exogene Komponente während der Dauer der Insulinbehandlung vorherrscht und vom Fettgehalt der Diät unabhängig ist. Nach Insulinentzug ist eine Erhöhung der Serumtriglyceride nachweisbar, die sich hauptsächlich in der endogenen Komponente widerspiegelt. Die Ergebnisse deuten darauf hin, daß in der Nahrung zugeführte Sukrose oder Eiweiß zu dieser endogenen Hypertriglyceridaemie beitragen.

Key words: Streptozotocin diabetes, hypertriglyceridemia, lipoprotein, diet.

The discrepancy in the studies cited above suggested that the nature of the hyperlipidemia might depend on the degree of diabetic control as well as the composition of the diet and led to the following study in which diets of varying composition were fed to streptozotocin diabetic rats with varying degrees of diabetic control.

\section{Methods \\ Handling of Animals}

Male rats were obtained from the Sprague-Dawley Company, Madison, Wisconsin and placed on standard rat chow diet (Teklad) ${ }^{1}$ and water ad libitum. Food intake was measured daily and body weight at varying intervals. After nine days, when weighing approximately $200 \mathrm{~g}$, fed rats were selected at random and injected intraperitoneally with $85 \mathrm{mg}$ of streptozotocin $^{2}$ per kilogram body weight to produce diabetes

13.44 calories $/ g ; 24.7 \%$ protein, $6.5 \%$ fat, $55.7 \%$ carbohydrate, $3.3 \%$ fiber, and $5 \%$ minerals.

2 A solution of streptozotocin, $40 \mathrm{mg} / \mathrm{ml}$ of saline, was prepared, brought to $\mathrm{pH} 4$ with $0.05 \%$ citric acid and used within 2 min. Streptozotocin was kindly supplied by William P. Dulin, Ph.D., Upjohn Co., Kalamazoo, Michigan. 
mellitus. For $24 \mathrm{~h}$ after streptozotocin injection these rats were given $\mathbf{5} \%$ glucose in their drinking water. Forty eight hours after injection of streptozotocin, blood glucose was estimated by dextrostix and a reflectance meter [7] and animals were considered to be diabetic if their blood glucose was greater than $280 \mathrm{mg} / 100 \mathrm{ml}$. Three days after injection of streptozotocin diabetic animals were matched according to blood glucose and body weight. One of each pair was placed randomly on high and low fat diets ${ }^{3}$ which were continued throughout the remainder of the study. Control animals received no injections, were paired according to body weight and placed on either of the two diets. The following day, protamine zinc insulin, 2.5 units per kilogram body weight, was given to each diabetic rat. During the ensuing 16 days, the insulin dosage was increased stepwise to achieve better control of the diabetes. At the end of this period the following dosage schedules ${ }^{4}$ were established: Rats on a high fat diet; 3 units of regular insulin per kilogram body weight at $8: 30$ and $12: 30 \mathrm{~h}$ and 4 units protamine zine insulin per kilogram at $16: 30 \mathrm{~h}$; Rats on a low fat diet; 5 units of regular insulin per kilogram body weight at $8: 30$ and $12: 30 \mathrm{~h}$ and 5 units of protamine zinc insulin per kilogram at $16: 30 \mathrm{~h}$. This regimen was continued for the remaining 12 days of insulin therapy. The last insulin injection was given on the 41st day (8:30) and between 2 and $4 \mathrm{~h}$ after that injection, heparinized blood was obtained from the femoral vein of both control and diabetic rats under light ether anesthesia. Forty eight hours later heparinized blood was obtained by cardiac puncture.

\section{Blood Glucose and Plasma Lipid Determinations}

An aliquot of the heparinized blood was taken immediately for glucose determination by a glucose oxidase method (Glucostat: Worthington Biochem. Corp.). The remainder was chilled, centrifuged and the plasma separated. Aliquots were frozen for subsequent determination of cholesterol by an automated ferric

3 Diets were obtained from Nutritional Biochemicals Corporation. The high fat diet (3.41 calories/g) contained $25 \%$ fat, $9 \%$ carbohydrate and $20 \%$ protein on a weight basis. The low fat diet (2.18 calories/g) contained $3 \%$ fat, $12 \%$ carbohydrate and $35 \%$ protein. The remaining portion of both diets consisted of minerals $(4 \%)$, fiber $(42-44 \%)$ and vitamins. Sixty six percent of the total calories in the high fat diet were derived from fat, $11 \%$ from carbohydrate and $23 \%$ from protein whereas for the low fat diet $12 \%$ of calories were derived from fat, $22 \%$ from carbohydrate and $66 \%$ from protein. Fat was provided as vegetable oil, carbohydrate as sucrose and protein as vitamin-free casein.

4 Although the animals given streptozotocin were selected at random and the degree of diabetes for each dietary group was comparable prior to insulin, the rats on a low fat diet tended to have higher blood glucoses, presumably due to the higher content of dietary sucrose $(22 \%$ vs $11 \%$ of total calories). Thus, to establish insulin dosages, blood glucose determinations were made on representative rats throughout a $24 \mathrm{~h}$ period after insulin injection. chloride method [8], triglyceride by an automated fluorescent technique [9], free fatty acid (FFA) by a colorimetric method using copper nitrate $[10]$ and total fat esters by a hydroxamic acid method [11]. The latter was modified in that the quantity of perchloric acid used in the preparation of acid perchlorate was doubled. Additional aliquots of plasma were kept at $4^{\circ} \mathrm{C}$ for subsequent lipoprotein electrophoresis which was conducted according to the method of Lees and Hatch [12] within one week ${ }^{5}$ of obtaining the specimens. The electrophoretograms were scanned with a densitometer (Photovolt Corp., New York, New York) at a wave length of $525 \mu$ and the area under each curve determined by an integrator attached to the scanner. The chromatograms were divided into 5 areas: alpha, beta-pre-beta ${ }^{6}$, origin, the area between alpha and pre-beta and the area between beta and the origin. Each area was expressed as a percentage of the total, but only the areas under the 3 major bands have been recorded in the results section. The lipid in each electrophoretic band was calculated by multiplication of the total lipid in each plasma sample [11] by the percent of lipid determined to be in each fraction by densitometry. The increase after insulin withdrawal was subsequently calculated.

\section{Results}

\section{Caloric Intake and Growth of Animals}

Food intake was less for diabetic rats on a high fat diet than those on a low fat diet (21 vs $32 \mathrm{~g} /$ day). Calorie concentration of the high fat diet, however, was greater than the low fat diet (3.41 vs 2.18 calories/ gram). Thus, caloric intake was found to be equal for both groups of diabetic rats and for the control rats on a high fat diet. The last eleven days are pictured in Fig. 1. Only the control animals on a low fat diet ingested less calories per day. In each instance, caloric intake decreased on day 42 after the blood drawing prior to insulin withdrawal. In all instances caloric intake had returned almost to prior levels by $48 \mathrm{~h}$.

Body weight of each group of animals increased equally during the first 9 days prior to streptozotocin administration and then ceased in those rats made diabetic (Fig. 2). Body weight increased again in the diabetic animals as the insulin dose reached the final level for the last 10 days of therapy. The different diets did not lead to a significant difference in growth of either control or diabetic rats although the diabetic rats never reached the final weight of the controls.

5 That no change in the electrophoretogram was seen during this period of one wook was demonstrated by running representative normal and diabetic specimens immediately and again at the end of the period of analysis.

6 The beta and pre-beta bands were not consistently separated and have thus been considered togtheer. 


\section{Blood Glucose and Plasma Lipids}

Blood glucose was mildly elevated in both diabetic groups while on insulin treatment (Table 1). There was no significant difference between the 2 diabetic groups (high fat: $133 \pm 16$ vs low fat: $173 \pm 19$ ) but, compared with controls, the blood glucose was higher in the diabetic animals on a low fat diet $(173 \pm 19$ vs $104 \pm 4$, $p<0.025$ ). Forty eight hours after insulin withdrawal the blood glucose levels of each group of diabetic rats had risen significantly in comparison with controls $(p<0.001)$ and the difference between the levels of diabetic rats on a low fat diet as compared to a high fat diet was exaggerated $(414 \pm 16 \mathrm{vs} 284 \pm 15, p<0.001)$.
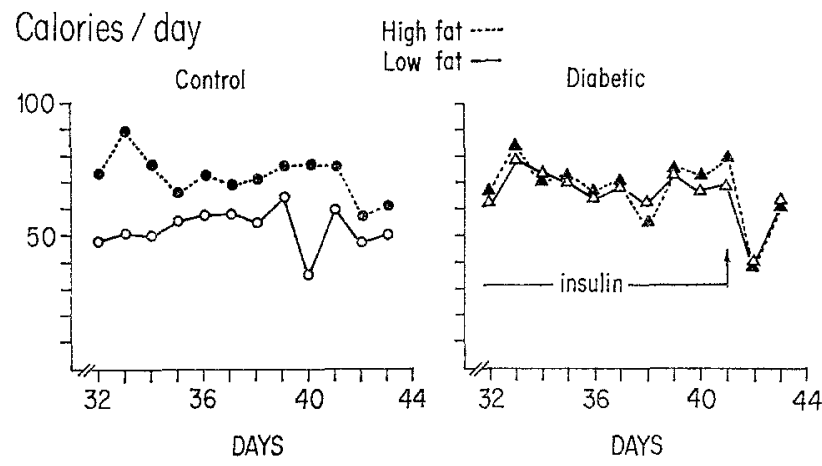

Fig. 1. Mean daily caloric intake of diabetic and control rats during the last 11 days of the study significantly greater than those on a high fat diet $(984 \pm 267$ vs $337 \pm 75, p<0.05)$. During insulin treatment, FFA levels were higher than control only in the diabetic rats on a high fat diet but after insulin withdrawal the FFA levels of the diabetic rats on a low fat diet rose markedly so that the final FFA levels of each diabetic group were not significantly different from one another $(1282 \pm 89$ vs $1450 \pm 53)$. Furthermore, despite the significant rise in the mean FFA and

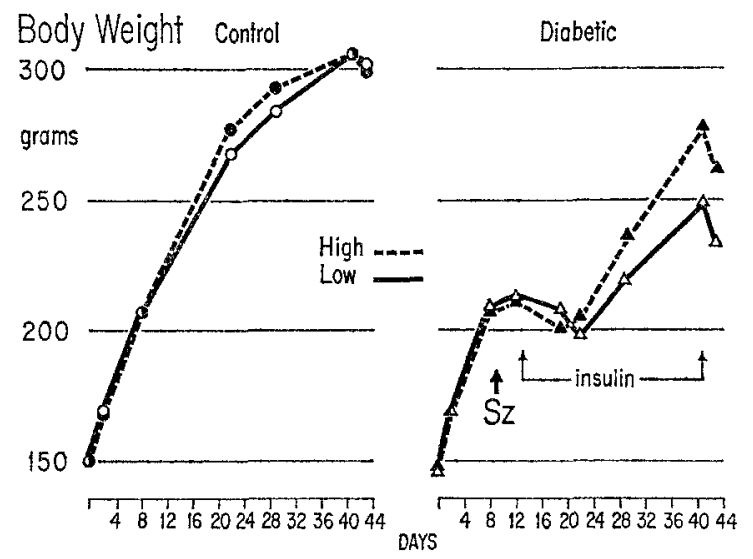

Fig. 2. Mean body weight of normal (control) and diabetic rats on low and high fat diet. The date of streptozotocin (Sz) injection is indicated as well as the period of insulin treatment of diabetic rats. For more details see text

Table 1. Blood glucose and plasma lipids in diabetic and control rats

\begin{tabular}{|c|c|c|c|c|c|}
\hline \multirow[b]{2}{*}{ Determination } & \multirow[b]{2}{*}{ Insulin ${ }^{\mathbf{a}}$} & \multicolumn{2}{|c|}{ High fat } & \multicolumn{2}{|c|}{ Low fat } \\
\hline & & $\begin{array}{l}\text { Diabetic } \\
\text { (11) }\end{array}$ & $\begin{array}{l}\text { Control } \\
(8)\end{array}$ & $\begin{array}{l}\text { Diabetic } \\
(\mathbf{1 3})\end{array}$ & $\begin{array}{l}\text { Control } \\
(8)\end{array}$ \\
\hline $\begin{array}{l}\text { Glucose } \\
(\mathrm{mg} / 100 \mathrm{ml})\end{array}$ & \pm & $\begin{array}{l}133 \pm 16 \\
284 \pm 15\end{array}$ & $\begin{array}{r}103 \pm 3 \\
97 \pm 7\end{array}$ & $\begin{array}{l}173 \pm 19 \\
414 \pm 16\end{array}$ & $\begin{array}{r}104 \pm 4 \\
99 \pm 3\end{array}$ \\
\hline $\begin{array}{l}\text { Cholesterol } \\
(\mathrm{mg} / 100 \mathrm{ml})\end{array}$ & \pm & $\begin{array}{ll}82 \pm & 3 \\
88 \pm & 4\end{array}$ & $\begin{array}{l}92 \pm 4 \\
88 \pm 3\end{array}$ & $\begin{array}{l}77 \pm \quad 3 \\
97 \pm 10\end{array}$ & $\begin{array}{l}71 \pm 9 \\
89 \pm 4\end{array}$ \\
\hline $\begin{array}{l}\text { Triglyceride } \\
(\mathrm{mg} / 100 \mathrm{ml})\end{array}$ & + & $\begin{array}{l}228 \pm 51 \\
337 \pm 75\end{array}$ & $\begin{array}{l}75 \pm 13 \\
52 \pm 11\end{array}$ & $\begin{array}{l}276 \pm \quad 44 \\
984 \pm 267\end{array}$ & $\begin{array}{l}94 \pm 10 \\
55 \pm 6\end{array}$ \\
\hline $\begin{array}{l}\text { FFA } \\
(\mu \mathrm{Eq} / L)\end{array}$ & + & $\begin{array}{r}994 \pm 130 \\
1282 \pm 89\end{array}$ & $\begin{array}{l}523 \pm 86 \\
696 \pm 50\end{array}$ & $\begin{array}{r}644 \pm 53 \\
1450 \pm 153\end{array}$ & $\begin{array}{l}510 \pm 55 \\
504 \pm 37\end{array}$ \\
\hline
\end{tabular}

Although minor changes in cholesterol were noted, none were significant and the major effect of diabetes on plasma lipids was a $\mathbf{3}$ fold increase in triglyceride levels which was independent of diet before insulin withdrawal (Table 1). Forty eight hours after insulin withdrawal the triglyceride level of rats on a high fat diet had risen modestly but not significantly (from $228 \pm 51$ to $337 \pm 75$ ) whereas the triglyceride level of rats on a low fat diet had risen significantly (from $276 \pm 44$ to $984 \pm 267, p<0.025$ ) and the final triglyceride levels of diabetic rats on a low fat diet were triglyceride levels in diabetic rats on a low fat diet, there was no correlation between the rise in FFA and the rise in triglyceride in individual animals $(r=$ $-0.298, p>0.1$ ).

\section{Plasma Lipoproteins}

The lipoprotein electrophoretic pattern was similar for plasma from control animals on a high and low fat diet and there was no change over the last 2 days of study (Table 2). The electrophoretic pattern of plasma from diabetic rats showed marked differences from 
normal. Regardless of diet, the percent of exogenous lipoproteins (origin) was elevated during insulin therapy. Forty eight hours after insulin withdrawal, the exogenous component was still present but the most marked change was a significant increase in the betapre-beta fraction on both diets (high fat: $24 \pm 2 \%$ vs $11 \pm 1, p<0.001$ and low fat: $32 \pm 2 \%$ vs $17 \pm 3$, $p<0.001)$.
In interpreting the results of these experiments, one must first consider the 2 variables under study; diet and insulin administration. Since previous reports indicated that the amount of fat in the diet affected the level of serum triglycerides in untreated diabetic rats [2], an initial goal of this study was to provide one group of rats with a high fat and another with a low fat diet. A pilot study demonstrated that whereas

Table 2. Lipoprotein electrophoresis of plasma from diabetic and control rats

\begin{tabular}{|c|c|c|c|c|c|}
\hline \multirow{2}{*}{$\begin{array}{l}\text { Lipoprotein } \\
\text { fraction } \\
\text { (\% of total) }\end{array}$} & \multirow[b]{2}{*}{ Insulin ${ }^{a}$} & \multicolumn{2}{|c|}{ High fat } & \multicolumn{2}{|c|}{ Low fat } \\
\hline & & $\begin{array}{l}\text { Diabetic } \\
\text { (11) }\end{array}$ & $\begin{array}{l}\text { Control } \\
(8)\end{array}$ & $\begin{array}{l}\text { Diabetic } \\
\text { (13) }\end{array}$ & $\begin{array}{l}\text { Control } \\
\text { (8) }\end{array}$ \\
\hline Origin & + & $\begin{array}{l}36 \pm 3 \\
26 \pm 3\end{array}$ & $\begin{array}{l}5 \pm 1 \\
7 \pm 1\end{array}$ & $\begin{array}{l}28 \pm 3 \\
21 \pm 2\end{array}$ & $\begin{array}{l}4 \pm 1 \\
5 \pm 1\end{array}$ \\
\hline$\beta$-pre $\beta$ & + & $\begin{array}{l}11 \pm 1 \\
24 \pm 2\end{array}$ & $\begin{array}{l}31 \pm 3 \\
28 \pm 3\end{array}$ & $\begin{array}{l}17 \pm 3 \\
32 \pm 2\end{array}$ & $\begin{array}{l}26 \pm 2 \\
29 \pm 2\end{array}$ \\
\hline Alpha & \pm & $\begin{array}{l}42 \pm 4 \\
36 \pm 5\end{array}$ & $\begin{array}{l}52 \pm 3 \\
57 \pm 3\end{array}$ & $\begin{array}{l}35 \pm 5 \\
23 \pm 4\end{array}$ & $\begin{array}{l}57 \pm 2 \\
57 \pm 2\end{array}$ \\
\hline
\end{tabular}

a $+=$ Diabetic rats on insulin (day 41 )

$-=$ Diabotic rats off insulin (day 43)

( ): Number of animals in each group.

Rosults recorded as mean \pm standard error of the mean.

The calculated increase of fat esters in the betapre-beta fraction after insulin withdrawal was greater for the low fat diet (low fat: $319 \pm 59 \mathrm{mg} / 100 \mathrm{ml}$ vs high fat: $127 \pm 34 \mathrm{mg} / 100 \mathrm{ml}, p<0.025$ ) (Table 3 ). In combination with the rise in triglycerides the data in Tables 2 and 3 imply an inrease in endogenous hypertriglyceridemia after insulin withdrawal which was more marked on the low fat diet.

Table 3. Inerease in lipid after insulin withdrawal

\begin{tabular}{lccc}
\hline & \multicolumn{3}{c}{ Lipoprotein fraction } \\
& Origin & $\beta$-pre & Alpha \\
\hline $\begin{array}{l}\text { High fat } \\
\text { (11) }\end{array}$ & $10 \pm 36$ & $127 \pm 34$ & $36 \pm 21$ \\
$\begin{array}{l}\text { Low fat } \\
\text { (13) }\end{array}$ & $104 \pm 48$ & $319 \pm 59$ & $69 \pm 31$ \\
\hline
\end{tabular}

( ): Number of animals in each diabetic group.

Results are recorded as mean \pm standard error of the mean. Calculations are based on multiplying the total lipid (11) by the \% lipid in each lipoprotein fraction (Table 2).

\section{Discussion}

The hypertriglyceridemia seen in experimental diabetes has been shown to be exogenous in origin [2]. However, there are many examples of endogenous hypertriglyceridemia in experimental as well as clinical diabetes $[4,5,6]$. Since the discrepancy might be explained by the degree of diabetic control and/or the composition of the diet, the present study was designed to investigate the effect of diet on the hypertriglyceridemia manifested by diabetic rats after insulin withdrawal. diabetic rats consumed normal amounts of the high fat diet, they ate only small amounts of an isocaloric fat-free diet containing large amounts of sucrose. While on the latter diet, the rats looked ill, lost weight rapidly, developed marked hyperglycemia and hypertriglyceridemia and many of them died. For these reasons dietary sucrose was subsequently reduced to $22 \%$ of total calories, an amount still double that of the "high fat" diet. The decrease in caloric content caused by the reduction of sucrose was minimized by a relative increase of protein which provided $66 \%$ of calories in the "low fat" diet. With this alteration of the "low fat" diet composition the untoward effects of the high dietary sucrose were eliminated and caloric intake became identical with that of animals on the "high fat" diet (Fig. 1).

The design involving insulin treatment and withdrawal was based on reports that rats with experimental diabetes are resistant to ketoacidosis unless treated with insulin which is subsequently stopped [13]. The amounts of insulin administered in this experiment were comparable to those previously shown to provide satisfactory control of blood glucose in diabetic rats and to result in markedly uncontrolled diabetes after withdrawal of insulin $[1,13]$.

The present study differs in many respects from a previous study by Bierman on the origin of hypertriglyceridemia in experimentally induced diabetes of rats [2] in that we used streptozotocin to induce diabetes [14], varied but did not completely eliminate the fat content of the diet and varied the control of diabetes by giving insulin for one month and then with. drawing it.

The animals on a "low fat" diet appeared to 
manifest a more severe form of diabetes as evidenced by the high blood glucose concentration despite a larger dose of insulin and by the more marked elevation of blood glucose caused by insulin withdrawal. This was due presumably to the higher sucrose content of the "low fat" diet in comparison with the "high fat" diet (22 vs $11 \%$ of total calories). Since the caloric intake of both groups of diabetic rats was the same, those on the "low fat" diet consumed three times as much protein and twice as much carbohydrate as those on the high fat diet and it is presumed that the higher carbohydrate intake was sufficient to aggravate the hyperglycemia of the streptozotocin diabetic animals.

Circulating plasma lipid particles may be separated by lipoprotein electrophoresis into exogenous (dietary) or endogenous (synthesized in vivo) [15]. The latter may be the result of synthesis from dietary components such as carbohydrate, or from endogenous sources such as FFA released from adipose tissue stores.

Triglyceride levels of diabetic animals on insulin therapy were 3 times higher than in controls, were independent of diet, and primarily of exogenous origin. These data imply a decreased clearance of dietary lipid which might be due to the known decrease of lipoprotein lipase activity present in insulin deficiency states [1]. This hypothesis is further supported by the finding of a higher exogenous lipid component in diabetic rats on the high fat diet.

Insulin treatment appears to have produced a restraining effect on the triglyceride rise in diabetic rats as evidenced by a further rise of plasma triglyceride after insulin withdrawal which was more marked in rats on the "low fat" diet. This triglyceride rise was accompanied by a marked increase in the percent of lipoproteins in the beta-pre-beta fraction which, combined with the fact that cholesterol did not change significantly, suggested an increase in endogenous hypertriglyceridemia after insulin withdrawal. Furthermore, assuming that the intensity of staining of each electrophoretic band was linearly related to the amount of lipid present, an absolute increase of fat esters was found in the beta-pre-beta electrophoretic band after insulin withdrawal which was more pronounced on the "low fat" than on the "high fat" diet (Table 3).

Although the data are in agreement with those of Bierman et al. [2] in showing the presence of an exogeous component in the hypertriglyceridemia of experimental diabetes in the rat, they differ considerably in that they demonstrate a significant endogenous component after insulin withdrawal. While the difference might be due to the different manner by which diabetes was induced in the two studies, it is more likely that the diabetes was more severe in our diabetic rats after insulin withdrawal.

The source of the endogenous lipid particles cannot be identified on the basis of the present study. One possible source would be FFA released from adipose tissue, esterified in the liver and converted into lipo- proteins. However, the similarity of FFA levels in the two groups of diabetic rats after insulin withdrawal and the fact that the rise in triglyceride levels did not correlate with the rise in FFA levels in individual rats do not support this hypothesis. If the free fatty acids cannot be held solely responsible for the marked increase in triglyceride of the low fat diet group, one must consider the higher content of dietary sucrose or protein in the "low fat" group as a possible contributing factor to the hypertriglyceridemia after insulin withdrawal. The known effect of sucrose in promoting endogenous hypertriglyceridemia $[16,17,18]$ suggests that the difference in the two dietary groups was due to the differing sucrose content of the diets.

Thus, we conclude that both exogenous and endogenous types of hypertriglyceridemia are present in streptozotocin diabetes, that the exogenous component predominated during insulin treatment and was independent of dietary fat. Although the exogenous component increased after insulin withdrawal, the endogenous component predominated. The relative contribution of dietary sucrose and protein to this hypertriglyceridemia is presently under study.

Acknowledgement. This work was supported in part by a Buswell Fellowship (C.C.) from the State University of New York at Buffalo and a Diabetes Training Program, NIAMD AM-05507-04. - The authors appreciate the technical assistance of Miss Diana Hojnicki, Mr. David Kolody, Mrs. Bona Marotta and Miss Pat Zuber.

\section{References}

1. Schnatz, J.D., Williams, R.H.: The effect of acute insulin deficiency in the rat on adipose tissue lipolytic activity and plasma lipids. Diabetes 12, 174 (1963).

2. Bierman, E.L., Amaral, J.A.P., Belknap, B.H.: Hyperlipemia and diabetes mellitus. Diabetes 15, 675 (1966).

3. Bagdade, J.D., Porte, D., Jr., Bierman, E.L.: Diabetic lipemia: A form of acquired fat-induced lipemia. N.E.J. Med. 276, 427 (1967).

4. Kaufmann, N.A., Gutman, A., Barzilai, D., Eschar, J., Blondheim, S.H., Stein, Y.: Hypertriglyceridemia induced by dietary fat or carbohydrate and by uncontrolled diabetes. Israel J. med. Sci. 1, 389 (1965).

5. Dangerfield, W.G. and Smith, E. B.: An investigation of serum lipids and lipoproteins by paper electrophoresis. J. clin. Path. 8, 132 (1955).

6. O'Connor, T.P., Schnatz, J.D.: Lipoprotein lipase activity and hypertriglyceridemia in alloxan diabetic rabbits. Metabolism 17, 838 (1968).

7. Jarret, R.J., Keen, H., Hardwick, C.: "Instant" blood sugar measurement using dextrostix and a reflectance meter. Diabetes 19, 724 (1970).

8. Levine, J.B., Zak, B.: Automated determination of serum total cholesterol. Clin. chim. Acta 10, 381 (1964).

9. Kessler, G., Lederer, H.: Fluorometric measurement of triglycerides; Technicon Symposium on "Automation in Analytical Chemistry" New York, New York, 1965.

10. Mahadevan, S., Dillard, C.J., Tappel, A.L.: A modified colorimetric micro method for long-chain fatty acids and its application for assay of lipolytic enzymes. Anal. Biochem. 27, 387 (1969). 
11. Snyder, F., Stephens, N.: A simplified spectrophotometric determination of ester groups in lipids. Biochim biophys Acta 34, 444 (1959).

12. Lees, R.W., Hatch, F.T.: Sharper separation of lipoprotein species by paper electrophoresis in albumincontaining buffer. J. Lab. clin. Med. 61, 518 (1963).

13. Steiner, D.F., Rauda, V., Williams, R.H.: Severe Ketoacidosis in the alloxan diabetic rat. Endocrinol. 68, 809 (1961).

14. Junod, A., Lambert, A.E., Orci, L., Pictet, R., Gonet, A.E., Renold, A.E.: Studies of the diabetogenic action of streptozotocin. Proc. Soc. exper. Biol. 126, 201 (1967).

15. Lees, R.S., Fredrickson, D.S.: The differentiation of exogenous and endogenous hyperlipemia by paper electrophoresis. J. clin. Invest. 44, 1968 (1965).
16. Nestel, P.J., Carroll, K.F., Havenstein, N.: Plasma triglyceride response to carbohydrate, fats and caloric intake. Metab. 19, 1 (1970).

17. Lawson, D.H., Gale, M.: Effect of short-term sucrose restriction on serum lipid levels. Lancet 1966 II, 1379.

18. Hill, P.: Effect of fructose on rat lipids. Lipids 5, 621 (1970).

J. David Schnatz, M.D., Department of Medicine, State University of New York at Buffalo, and the E.J. Meyer Memorial Hospital, 462 Grider Street,

Buffalo, New York 14215, U.S.A. 